\title{
The Use of the Usability Scale System as an Evaluation of the Kampung Heritage Kajoetangan Guide Ebook Application
}

\author{
Baroroh Lestari, P. Ita Rifiani, and A. Becik Gati
}

\section{ABSTRACT}

\begin{abstract}
The development of information technology these days allows tourists to get information about tourist destinations very easily. One of the ways to get information about tourist destinations is from a guidebook. The purpose of this study is to evaluate the Kampung Heritage Kajoetangan's e-book application using the System Usability Scale method. The data was collected using a questionnaire. The respondents of this study are 40 people. The results show that the respondents considered the Kajoetangan travel guide e-book is already good and acceptable. However, looking at the NPS, the respondents tend to behave as promoters. Therefore, it is necessary to provide education and introduction of the application to the users (e.g. tour guides and the public). Thus, the problem of the lack of experience in trying the Kajoetangan travel guide e-book can be solved. In addition, developers, in this case, the researchers, must also improve the application, particularly regarding the complexity of the application so the public and tour guides, as the target users, can easily use it.
\end{abstract}

Keywords: kajoetangan, travel guide, usability method.

\author{
Submitted : September 15, 2021 \\ Published : December 07, 2021 \\ ISSN: $2507-1076$ \\ DOI: $10.24018 / \mathrm{ejbmr} .2021 .6 .6 .1113$ \\ Baroroh Lestari* \\ State Polytechnic of Malang, Malang, East \\ Java, Indonesia. \\ (e-mail: baroroh.lestari@ polinema.ac.id) \\ P. Ita Rifiani \\ State Polytechnic of Malang, Malang, East \\ Java, Indonesia. \\ (e-mail: ita_djatmika ${ }^{\circledR}$ yahoo.com) \\ A. Becik Gati \\ State Polytechnic of Malang, Malang, East \\ Java, Indonesia. \\ (e-mail: gatianjari@gmail.com) \\ *Corresponding Author
}

\section{INTRODUCTION}

Today, information and communication technology has developed rapidly. Mobile tourism is one of the emerging trends in the tourism sector by using a Smartphone device as an electronic guide. Prior to these advances in information technology, tourists used printed travel guide books before and during the trip (Fernandes et al., 2017). Since the early 2000s, the market for guidebooks has shrunk due to the developments in information technology, and particularly the ubiquitous Internet access via various devices, such as smartphones and tablets.

The use of information technology has been proven to bring changes in the use of travel guidebooks (Fujii et al., 2016; Peel et al., 2016). Guidebooks can be seen as the mediator of tourist experience (Peel et al., 2016). In addition, guidebooks are objects that can describe the destination and culture where the book was produced, as well as the values of the community at the time the book was written (Mielie, 2017). Thus, tourists can discover the condition of tourist destinations (Peel et al., 2016), and the destination nicknames (Mazor-Tregerman et al., 2017). Moreover, recent research shows that the tourists' information needs are changing in the digital era (Choe et al., 2017). With the development of information technology, it is possible to develop an e-book application for travel guides. An Android-based mobile tourism application provides information for tourists quickly and in real-time. In developing a good application, proper usability testing is needed (Afrina et al., 2017).
Usability in mobile applications allows different interactions with desktop-based applications. This is because mobile devices have various forms and operating systems. In general, for application development and implementation, usability testing is rarely carried out. Most of them are directly implemented and used because the development is still centered on the functional and non-functional needs of the users, but not yet on the main needs (Kusuma et al., 2016). Usability testing is conducted with the aim of finding errors that can affect application interaction with the users. In addition, application testing is also performed to test the function of the application so it can run as desired. Usability mostly suggests that a system or service can be used by a particular user to get the designated purpose with effectiveness, efficiency, and satisfaction. Therefore, it is necessary to test the usability of the travel guide e-book for Kampung Kajoetangan.

\section{RESEARCH METHODS}

This study used the System Usability Scale (SUS) in the form of a questionnaire to measure the computer system's usability according to the user's subjective point of view (Brooke, 2013). This measurement system was developed by John Brooke in 1986. SUS is widely used to measure usability up to now, and it also has several advantages, including: (1) SUS is easy to use and the result is in a score of 0-100 (Brooke, 1996), (Ramadhan, D.W. et al., 2019); (2) SUS does not require complicated calculations (Bangor et al., 2009); (3) 
SUS is free of charge, and does not require additional costs (Garcia, 2013); and (4) SUS is proven to be valid and reliable, even though using a small sample size (Brooke, 2013). SUS is a questionnaire with 10 question items as shown in Table 1. The questionnaire uses a 5-point Likert scale for the responses, consisting of "Strongly disagree", "Disagree", "Neutral", "Agree", and "Strongly agree". The questionnaires were distributed to 40 random people.

TABLE I: SUS QUESTIONNAIRE

\begin{tabular}{|c|c|}
\hline No & Statements \\
\hline 1 & $\begin{array}{l}\text { I will often use the Kajoetangan travel guide e-book when } \\
\text { traveling to Kampung Heritage Kajoetangan. }\end{array}$ \\
\hline 2 & $\begin{array}{l}\text { This Kajoetangan travel guide e-book is too complex (contains a } \\
\text { lot of unnecessary things). }\end{array}$ \\
\hline 3 & The travel guide e-book is easy to use. \\
\hline 4 & $\begin{array}{l}\text { I need technical assistance to use the Kajoetangan travel guide e- } \\
\text { book. }\end{array}$ \\
\hline 5 & The menus in the Kajoetangan travel guide e-book work well. \\
\hline 6 & $\begin{array}{l}\text { There are many inconsistencies in the Kajoetangan travel guide e- } \\
\text { book. }\end{array}$ \\
\hline 7 & $\begin{array}{l}\text { In my opinion, the features in the Kajoetangan travel guide e- } \\
\text { book are interconnected, making it easier to use. }\end{array}$ \\
\hline 8 & $\begin{array}{l}\text { In my opinion, the Kajoetangan travel guide e-book is } \\
\text { complicated to use. }\end{array}$ \\
\hline 9 & I feel confident when using the Kajoetangan travel guide e-book. \\
\hline 10 & $\begin{array}{l}\text { I need to learn a lot of things before I can use the Kajoetangan } \\
\text { travel guide e-book well. }\end{array}$ \\
\hline
\end{tabular}

Furthermore, the results of the calculation of the SUS method were converted to numbers from 1-100. The numbers were used to determine whether the product is feasible or not to be used (Pudjoatmodjo \& Wijaya, 2016; Ramadhan et al., 2019). The SUS assessment is as follows:

a. Statements with odd numbers were calculated as follows: the respondent's response was minus by 1 .

b. Statements with even numbers were calculated as follows: the number 5 was subtracted from the respondent's response.

c. The respondents' values were then summed up. Afterwards, the result was multiplied by 2.5 (Ramadhan et al., 2019).

Next to clarify the calculation process, can be seen from the equation below:

$$
\begin{aligned}
\text { Respondent score }= & ((Q 1-1)+(5-Q 2)+(Q 3-1)+(5-Q 4) \\
& +(Q 5-1)+(5-Q 6)+(Q 7-1)+(5-Q 8) \\
& +(Q 9-1)+(5-Q 10)
\end{aligned}
$$

Description:

Respondents Score = Score obtained from each respondent; Q1...Q10 = Likert's value of each statement from the respondent (Kharis et al., 2019; Pudjoatmodjo \& Wijaya, 2016).

The SUS score equation for all respondents as follows:

$$
\text { Skor SUS }=\sum_{i-1}^{n} \frac{X_{i}}{n}
$$

Description:

$\mathrm{X}_{\mathrm{i}}=$ Total score of each respondent;

$\mathrm{n}=$ The number of respondents (Kharis et al., 2019).
After obtaining the SUS value, then the results of the SUS scores were interpreted into the SUS score scale. The interpretation was carried out in 5 ways, namely:

1. Percentile ranks

The results of the calculation of the obtained SUS score were then converted into percentile rankings. The percentile score is the SUS score that is in the percentile range. The average SUS score, in general, is 68 (at the $50^{\text {th }}$ percentile). This shows that a SUS score above 68 means above average, and below 68 means below average (Sauro, 2018).

\section{Grade}

The next interpretation related to percentile rank is grade. In this assessment, the SUS score was categorized in the grades range from $\mathrm{A}+$ to $\mathrm{F}$. Grade $\mathrm{A}$, indicates superior performance, then $\mathrm{C}$ indicates average, while $\mathrm{F}$ indicates that the performance failed (Sauro, 2018).

\section{Adjectives}

The adjective scale contains adjectives, which include Good, - Okay, and - Bad. Users are associated with users in using a product. For example, a SUS score above 85 is associated with - Excellent. "Good" is just above the average of 71, and - OK is for a score of 51 (Sauro, 2018).

\section{Acceptability}

The SUS score is far above the average or far below the average. A SUS score above 70 (above the average of 68) is categorized as acceptable, and categorized as unacceptable if the SUS score is below 50 (closely related to the designation of scores that is lower than 51.6 with an $\mathrm{F}$ grade). A range score between 50-70 is defined as marginally - acceptable, covering the range from $\mathrm{C}$ to $\mathrm{D}$ on the grading scale. Figure 1 shows the SUS Score on the Acceptability Scale (Bangor et al., 2009; Sauro, 2018).

\section{Promoters and Detractors}

There is a strong relationship between SUS and Net Promoter Score (NPS). The average SUS describes the variation between $30 \%$ and $50 \%$ in the users' likelihood to recommend the application. NPS designates three classifications of recommenders based on the respondents' responses with 11 points (from 0 to 10). The promoter classification was given a score of 9 and 10, the passive classification was given a score of 7 and 8 , and the detractor classification was given a score of 6 and below. The promoter classification is more likely to recommend a

\begin{tabular}{|c|c|c|c|c|c|}
\hline Grade & SUS & $\begin{array}{c}\text { Percentile } \\
\text { Range }\end{array}$ & Adjective & Acceptable & NPS \\
\hline $\mathrm{A}+$ & $84.1-100$ & $96-100$ & $\begin{array}{c}\text { Best } \\
\text { Imaginable }\end{array}$ & Acceptable & Promoter \\
\hline A & $80.8-84.0$ & $90-95$ & Excellent & Acceptable & Promoter \\
\hline A- & $78.9-80.7$ & $85-89$ & & Acceptable & Promoter \\
\hline $\mathrm{B}+$ & $77.2-78.8$ & $80-84$ & & Acceptable & Passive \\
\hline $\mathrm{B}$ & $74.1-77.1$ & $70-79$ & & Acceptable & Passive \\
\hline B- & $72.6-74.0$ & $65-69$ & & Acceptable & Passive \\
\hline $\mathrm{C}+$ & $71.1-72.5$ & $60-64$ & Good & Acceptable & Passive \\
\hline $\mathrm{C}$ & $65.0-71.0$ & $41-59$ & & Marginal & Passive \\
\hline $\mathrm{C}-$ & $62.7-64.9$ & $35-40$ & & Marginal & Passive \\
\hline $\mathrm{D}$ & $51.7-62.6$ & $15-34$ & Ok & Marginal & Detractor \\
\hline $\mathrm{F}$ & $25.1-51.6$ & $2-14$ & Poor & Not Acceptable & Detractor \\
\hline $\mathrm{F}$ & $0-25$ & $0-1.9$ & $\begin{array}{c}\text { Worst } \\
\text { Imaginable }\end{array}$ & Not Acceptable & Detractor \\
\hline
\end{tabular}
product/website/app to a friend, whereas the detractor classification is less likely to recommend (Sauro, 2018).

TABLE II: GRADING SCALE FOR SUS

Sources: (Lewis \& Sauro, 2018; Sauro, 2018). 


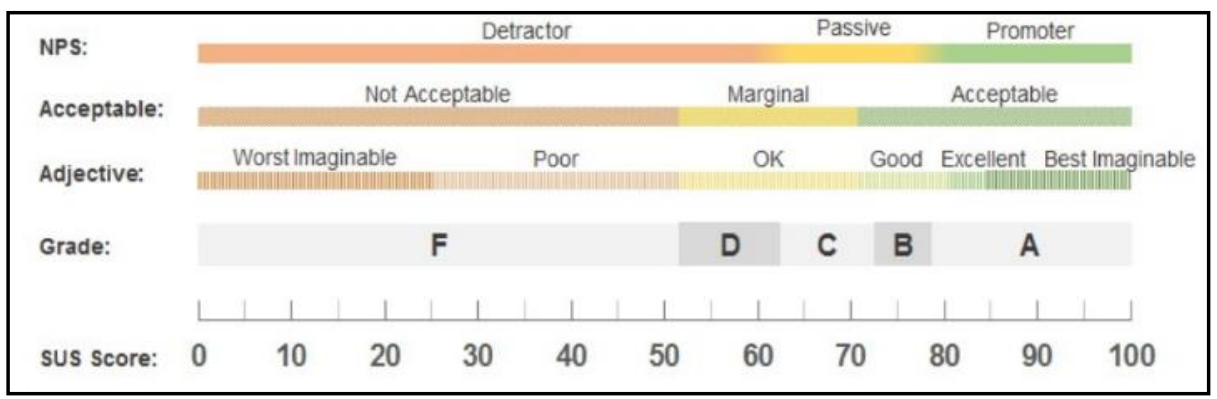

Fig. 1. Determination of Assessment Results. Sources: (Bangor et al., 2009; Sauro, 2018).

\section{RESULT AND DISCUSSION}

\section{A. Usability Testing}

This test is conducted to measure the level of satisfaction of using the system by the users. The benefits of usability testing are that developers can learn whether the application development is in accordance with the users' needs or not, so it becomes a benchmark for application success and is accepted by the users. In this study, to find out how effective, efficient, and satisfied the users are with the application, usability testing is performed. The application referred to in this study is a travel guide e-book for Kampung Kajoetangan. Subsequently, the respondents' level of satisfaction in using the application will be known. The questionnaire used to measure the SUS consists of 10 statement items as shown in Table I. Statements in odd numbers are positive sentences, and the score is $1-5$ for strongly disagree to strongly agree. Meanwhile, statements in even numbers are negative sentences, with the score ranging from 5-1 for strongly agree to strongly disagree. After the questionnaire was filled in, the data was then calculated according to the rules of calculating scores in SUS. The results of the distributed questionnaires to 40 respondents can be seen in Table III.

Table IV shows the calculation result of each respondent's SUS questionnaire scores with the provisions described previously.

TABLE III: THE RECAPITULATION OF RESPONDENS' ANSWERS

\begin{tabular}{ccccccccccc}
\hline No & Q1 & Q2 & Q3 & Q4 & Q5 & Q6 & Q7 & Q8 & Q9 & Q10 \\
\hline 1 & 5 & 2 & 4 & 2 & 4 & 1 & 4 & 3 & 4 & 3 \\
2 & 5 & 1 & 5 & 1 & 5 & 1 & 5 & 1 & 5 & 1 \\
3 & 5 & 2 & 4 & 2 & 4 & 1 & 4 & 3 & 4 & 3 \\
4 & 5 & 3 & 3 & 2 & 3 & 3 & 4 & 2 & 5 & 3 \\
5 & 4 & 3 & 3 & 3 & 3 & 3 & 4 & 2 & 4 & 3 \\
6 & 5 & 1 & 5 & 1 & 4 & 1 & 4 & 3 & 5 & 3 \\
7 & 5 & 2 & 5 & 2 & 3 & 3 & 4 & 2 & 4 & 2 \\
8 & 3 & 3 & 3 & 1 & 4 & 1 & 4 & 1 & 3 & 3 \\
9 & 5 & 2 & 4 & 2 & 5 & 2 & 4 & 2 & 4 & 1 \\
10 & 5 & 1 & 5 & 1 & 5 & 1 & 4 & 1 & 5 & 2 \\
11 & 4 & 2 & 4 & 2 & 4 & 2 & 3 & 2 & 4 & 2 \\
12 & 4 & 3 & 4 & 2 & 3 & 2 & 4 & 3 & 4 & 3 \\
13 & 5 & 2 & 5 & 2 & 3 & 2 & 4 & 3 & 3 & 2 \\
14 & 4 & 2 & 4 & 2 & 4 & 2 & 5 & 2 & 4 & 2 \\
15 & 4 & 3 & 4 & 2 & 3 & 2 & 4 & 3 & 4 & 3 \\
16 & 4 & 1 & 5 & 2 & 5 & 2 & 4 & 2 & 4 & 2 \\
17 & 4 & 2 & 4 & 2 & 4 & 2 & 5 & 2 & 4 & 2 \\
18 & 5 & 1 & 5 & 1 & 4 & 1 & 5 & 1 & 5 & 1 \\
19 & 4 & 3 & 4 & 2 & 4 & 2 & 3 & 3 & 4 & 2 \\
20 & 4 & 1 & 5 & 1 & 4 & 2 & 4 & 1 & 4 & 1 \\
21 & 5 & 1 & 5 & 1 & 5 & 1 & 5 & 2 & 5 & 1 \\
22 & 4 & 2 & 5 & 2 & 4 & 3 & 4 & 2 & 3 & 3 \\
23 & 4 & 2 & 3 & 2 & 4 & 2 & 4 & 3 & 4 & 2 \\
24 & 4 & 1 & 4 & 1 & 4 & 2 & 5 & 1 & 5 & 2 \\
25 & 5 & 2 & 4 & 5 & 4 & 2 & 4 & 3 & 5 & 2 \\
26 & 5 & 1 & 5 & 1 & 4 & 1 & 4 & 3 & 5 & 3
\end{tabular}

\begin{tabular}{lllllllllll}
27 & 5 & 1 & 5 & 1 & 4 & 2 & 5 & 2 & 5 & 2 \\
28 & 4 & 1 & 4 & 2 & 5 & 2 & 4 & 1 & 5 & 2 \\
29 & 5 & 2 & 4 & 2 & 5 & 2 & 5 & 3 & 4 & 1 \\
30 & 5 & 2 & 5 & 2 & 5 & 2 & 5 & 2 & 5 & 2 \\
31 & 5 & 1 & 5 & 1 & 4 & 2 & 5 & 2 & 5 & 2 \\
32 & 5 & 2 & 5 & 1 & 5 & 1 & 5 & 1 & 5 & 1 \\
33 & 4 & 2 & 4 & 2 & 4 & 2 & 4 & 2 & 4 & 2 \\
34 & 5 & 2 & 4 & 2 & 5 & 2 & 4 & 2 & 4 & 3 \\
35 & 5 & 1 & 4 & 1 & 5 & 2 & 5 & 1 & 5 & 1 \\
36 & 5 & 2 & 4 & 1 & 4 & 2 & 5 & 2 & 4 & 1 \\
37 & 5 & 1 & 5 & 1 & 4 & 1 & 5 & 2 & 5 & 1 \\
38 & 5 & 1 & 5 & 1 & 4 & 1 & 4 & 1 & 5 & 2 \\
39 & 5 & 1 & 4 & 2 & 5 & 1 & 5 & 1 & 5 & 1 \\
40 & 5 & 2 & 4 & 1 & 5 & 2 & 5 & 1 & 4 & 1 \\
\hline
\end{tabular}

Source: Primary Data from the Field (2021)

TABLE IV: THE CALCULATION RESULT OF SUS QUESTIONNAIRE SCORES

\begin{tabular}{|c|c|c|c|c|}
\hline $\begin{array}{l}\text { Odd } \\
\text { items }\end{array}$ & Even items & $\begin{array}{c}\text { SUS score } \\
(/ 100)\end{array}$ & Grades & $\begin{array}{l}\text { NPS } \\
\text { Score }\end{array}$ \\
\hline 16 & 14 & 75 & B & 6 \\
\hline 20 & 20 & 100 & A+ & 10 \\
\hline 16 & 14 & 75 & B & 6 \\
\hline 15 & 12 & 67,5 & C & 3 \\
\hline 13 & 11 & 60 & D & 1 \\
\hline 18 & 16 & 85 & $\mathbf{A +}$ & 10 \\
\hline 16 & 14 & 75 & B & 6 \\
\hline 12 & 16 & 70 & C & 3 \\
\hline 17 & 16 & 82,5 & $\mathbf{A}$ & 9 \\
\hline 19 & 19 & 95 & $\mathbf{A +}$ & 10 \\
\hline 14 & 15 & 72,5 & $\mathrm{C}+$ & 4 \\
\hline 14 & 12 & 65 & $\mathbf{C}$ & 3 \\
\hline 15 & 14 & 72,5 & $\mathrm{C}+$ & 4 \\
\hline 16 & 15 & 77,5 & B+ & 7 \\
\hline 14 & 12 & 65 & $\mathbf{C}$ & 3 \\
\hline 17 & 16 & 82,5 & $\mathbf{A}$ & 9 \\
\hline 16 & 15 & 77,5 & B+ & 7 \\
\hline 19 & 20 & 97,5 & $\mathbf{A +}$ & 10 \\
\hline 14 & 13 & 67,5 & C & 3 \\
\hline 16 & 19 & 87,5 & $\mathbf{A +}$ & 10 \\
\hline 20 & 19 & 97,5 & A+ & 10 \\
\hline 15 & 13 & 70 & $\mathbf{C}$ & 3 \\
\hline 14 & 14 & 70 & C & 3 \\
\hline 17 & 18 & 87,5 & $\mathbf{A +}$ & 10 \\
\hline 17 & 11 & 70 & C & 3 \\
\hline 18 & 16 & 85 & $A+$ & 10 \\
\hline 19 & 17 & 90 & $\mathbf{A +}$ & 10 \\
\hline 17 & 17 & 85 & $\mathbf{A +}$ & 10 \\
\hline 18 & 15 & 82,5 & $\mathbf{A}$ & 9 \\
\hline 20 & 15 & 87,5 & $A+$ & 10 \\
\hline 19 & 17 & 90 & $\mathbf{A +}$ & 10 \\
\hline 20 & 18 & 97,5 & $\mathbf{A +}$ & 10 \\
\hline 15 & 15 & 75 & $\mathbf{B}$ & 6 \\
\hline 17 & 14 & 77,5 & B+ & 7 \\
\hline 19 & 19 & 95 & $\mathbf{A +}$ & 10 \\
\hline 17 & 17 & 85 & $\mathbf{A +}$ & 10 \\
\hline 19 & 19 & 95 & $\mathbf{A +}$ & 10 \\
\hline 18 & 19 & 92,5 & A+ & 10 \\
\hline 19 & 19 & 95 & $\mathbf{A +}$ & 10 \\
\hline 18 & 18 & 90 & $\mathbf{A}$ & 10 \\
\hline \multicolumn{2}{|c|}{ Total Score of SUS } & 3268,5 & & \\
\hline & AVERAGE & 81,71 & $\mathbf{A}$ & \\
\hline
\end{tabular}

Source: Primary Data from the Field (2021). 
Based on the calculation result of each respondent's SUS scores as seen in Table IV, it is known that the highest score is 100 and the lowest is 60 . While the score that appears the most (mode) is 75. After the SUS score of each respondent is known, the next step is to calculate the average score by adding up all the scores and divided by the number of respondents. The total of the respondents' SUS scores in this study is 3268,5 . The total is shown in Table IV which was obtained from adding up the SUS scores of 40 respondents. Based on the total number, the average SUS score can be obtained by dividing the total SUS score by the number of respondents. Therefore, the average SUS score is 81,71. Fig. 2 shows the SUS scale of the results of the study.

\section{1,71}

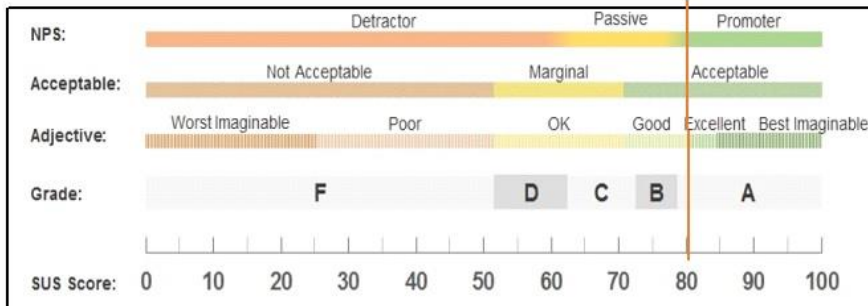

Fig 2. The Result of the SUS Scale. Source: Field Research Data (2021).

\section{B. Interpretation of the Results}

The next stage is interpreting the results of the SUS scores calculation into the score scale. Interpretation can be done in 5 ways (Sauro, 2018). The 5 methods are percentile rank, grade, adjective, acceptability, as well as promoters, and detractors. The test results are as follows:

\section{1) Percentile ranks}

The obtained SUS scores can be converted to percentile ranks. The conversion of SUS scores to percentiles can be seen in Table II. The percentile score is the SUS score that is in the percentile range. Fig. 3 shows the percentile ranking of this study by the SUS score threshold in general. The average SUS score in general (at the 50th percentile) is 68 . That means the SUS score above 68 is said to be above average, and below 68 means it is below average (Sauro, 2018). In this study, the SUS score is 81,71 , if it is associated with the general SUS score on the percentile ranking curve, the score is above average in general.

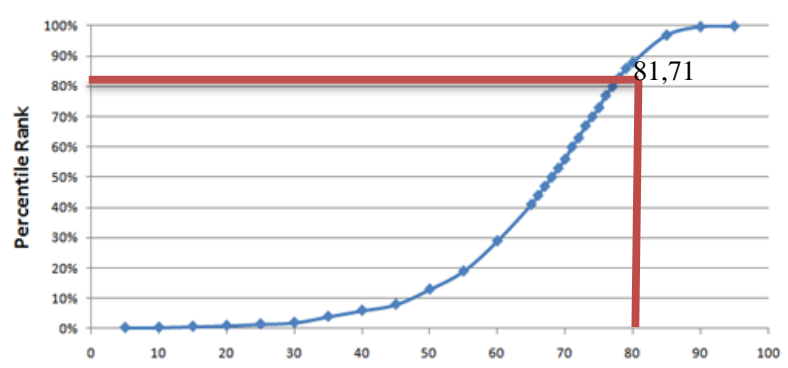

Fig 3. SUS Score Curve in Percentile. Source: Field Result Data (2021).

\section{2) Grade}

The next interpretation related to percentile rank is grade. In this scoring system, SUS categorizes scores in the grades range between $\mathrm{A}+$ to $\mathrm{F}$. Grade $\mathrm{A}$ indicates superior performance, to $\mathrm{F}$ (for failed performance), with $\mathrm{C}$ indicates average (Sauro, 2018). The SUS score obtained in this study is 81,71 , if we associate it with the grade scale in Figure 2, it could be seen that the score is in grade A (can be seen in Figure 2) which indicates the score is above average.

\section{3) Adjectives}

The adjective scale contains adjectives, which include Good, - Okay, and - Bad. Users are associated with users in using a product. For example, a SUS score above 85 is associated with - Excellent. "Good" is just above the average o.f 71, and - OK is for a score of 51 (Sauro, 2018). The SUS score in this study is 81,71 in which on the adjectives scale, the score is classified as excellent (can be seen in Figure 2). Thus, it can be said that the usability of the travel guide e-book according to the respondents is classified as excellent.

\section{4) Acceptability}

The fourth way of describing SUS is from the statements that are considered - acceptable or - unacceptable. Set these conditions in which when the SUS score is far above the average or far below the average. A SUS score above 70 (above the average of 68) is categorized as acceptable, and categorized as unacceptable if it is below 50 (closely related to the designation of scores that is lower than 51.6 with an $\mathrm{F}$ grade). Scores ranging from 50 to 70 are designated as marginally - acceptable, ranging from $\mathrm{C}$ to $\mathrm{D}$ on the grade scale (Bangor et al., 2009; Sauro, 2018). Fig. 2 shows the SUS score of the result in the Acceptability Scale. The SUS score obtained in this study is 81,71 which is above the average and categorized as acceptable. The usage of the travel guide e-book application can be accepted and used in general by the respondents.

\section{5) Promoters and Detractors}

There is a strong and consistent relationship between SUS and Net Promoter Score (NPS). The average SUS describes the variation between $30 \%$ and $50 \%$ in the users' likelihood to recommend the application. The NPS designates three classifications of recommenders based on the respondents' responses to 11 points (from 0 to 10). The promoter classification was given a score of 9 and 10, the passive classification was given a score of 7 and 8 , and the detractor classification was given a score of 6 and below (Sauro, 2018). The promoter classification is more likely to recommend a product/website/app to a friend, whereas the detractor classification is less likely to recommend. Figure 2 shows the relationship between NPS and SUS. When the SUS score is close to 81 on average, it is included in the promoter classification. Detractor classification was associated with an average SUS of 53 and below, also passive was the score in between (mean 70) (Sauro, 2018).

The SUS score in this study is 81,71 . If we associated the score with the NPS classification, it is in the early promoter category. Hence, the respondents in this study are known to be the early promoters of the travel guide e-book application. This is because the respondents want to recommend the application, but there are still doubts about recommending it. This condition can be seen from the respondents' responses which still expressing doubts in several statements, such as the Kajoetangan travel guide e-book is too complex, complicated when used, but the menus in the e-book function well. This causes the respondents to feel they need to learn many things before they can use the Kajoetangan travel guide e-book properly. 
TABLE V: Net PROMOTER SCORE CALCUlation

\begin{tabular}{lcc}
\multicolumn{3}{c}{ TABLE V: NET PROMOTER SCORE CALCULATION } \\
\hline Promoters & Number & Percentage \\
Neutrals & 22 & $55 \%$ \\
Detractors & 3 & $8 \%$ \\
\hline Total Responses & 15 & $38 \%$ \\
Net Promoter Score & 40 & $100 \%$ \\
\end{tabular}

Source: Field Research Data (2021).

The interpretation of the average SUS score obtained in this study can be seen in Table VI.

The average SUS score on the usability of the Kajoetangan travel guide e-book by 40 respondents is obtained 81,71 . The interpretation of these results shows that the score is in grade A with a percentile range of 90-95 (way above the average of 70). The classification shows that respondents assess the Kajoetangan travel guide ebook application as Excellent (adjective) and acceptable (acceptability). However, according to the NPS, respondents tend to behave as early promoters. This interpretation is supported by the background of the respondents who have minimal experience in trying the Kajoetangan travel guide e-book (it can be seen from the data on the respondents' responses who answered doubtfully for the 10th statement) because the respondents did not yet have an ideal picture of the application. Based on the results of the analysis, the developers, in this case, the researchers, need to improve the application, especially considering the complexity of the application so that it is easier to use by the public and tour guides as targets.

\begin{tabular}{|c|c|c|c|c|c|}
\hline Grade & SUS & $\begin{array}{c}\text { Percentile } \\
\text { Range }\end{array}$ & Adjective & Acceptable & NPS \\
\hline $\mathrm{A}+$ & $84.1-100$ & $96-100$ & $\begin{array}{c}\text { Best } \\
\text { Imaginable }\end{array}$ & Acceptable & Promoter \\
\hline A & $80.8-84.0$ & $90-95$ & Excellent & Acceptable & Promoter \\
\hline A- & $78.9-80.7$ & $85-89$ & & Acceptable & Promoter \\
\hline $\mathrm{B}+$ & $77.2-78.8$ & $80-84$ & & Acceptable & Passive \\
\hline B & $74.1-77.1$ & $70-79$ & & Acceptable & Passive \\
\hline B- & $72.6-74.0$ & $65-69$ & & Acceptable & Passive \\
\hline $\mathrm{C}+$ & $71.1-72.5$ & $60-64$ & Good & Acceptable & Passive \\
\hline $\mathrm{C}$ & $65.0-71.0$ & $41-59$ & & Marginal & Passive \\
\hline C- & $62.7-64.9$ & $35-40$ & & Marginal & Passive \\
\hline $\mathrm{D}$ & $51.7-62.6$ & $15-34$ & Ok & Marginal & Detractor \\
\hline $\mathrm{F}$ & $25.1-51.6$ & $2-14$ & Poor & $\begin{array}{c}\text { Not } \\
\text { Acceptable }\end{array}$ & Detractor \\
\hline $\mathrm{F}$ & $0-25$ & $0-1.9$ & $\begin{array}{c}\text { Worst } \\
\text { Imaginable }\end{array}$ & $\begin{array}{c}\text { Not } \\
\text { Acceptable }\end{array}$ & Detractor \\
\hline
\end{tabular}

\section{CONCLUSIONS}

The Kampung Kajoetangan travel guide e-book is an Android-based application. This application can be run using an Android-based mobile phone. The use of a guidebook in the form of an application is needed to support tourism activities in Malang City, East Java, Indonesia, especially Kampung Kajoetangan. The application that was made was tested on 40 respondents. The usability testing used the System Usability Scale (SUS) method consists of 10 positive and negative statements. The results of the test using the SUS method show that the average score of SUS using the Kajoetangan travel guide e-book application is 81,71 . The interpretation of the results shows that the score obtained is in grade A with a percentile range of 90-95 (already above the average, which is 70). These results indicate that the respondents considered the application of the Kajoetangan travel guide e-book to be excellent (adjective) and acceptable (acceptability). However, looking at the NPS category, respondents tend to behave as early promoters.

Therefore, it is necessary to provide in-depth education and introduction of the application to the users (e.g. tour guides and the public) by asking them to use the application. Thus, the problem of the lack of experience in trying the Kajoetangan travel guide e-book can be overcome. The emergence of this problem is because the respondents cannot imagine the ideal picture of the Kampung Kajoetangan travel guide e-book. Based on the results of the analysis, the developers, in this case, the researchers, also need to improve the application, especially considering the complexity of the application so that it is easier to use by the public and tour guides as the target users.

\section{ACKNOWLEDGMENT}

The authors would like to thank P2M State Polytechnic of Malang, East Java, Indonesia which has funded this research under the Applied Research Self-Funding DIPA Research Grant Scheme which was financed with DIPA fund number SP DIPA 023.18.2.677606/2021 with Letter of Agreement No: 5373/pl2 .1/hk/2021.

\section{REFERENCES}

Afrina, M., Ibrahim, A., \& Simarmata, T. (2017). Perancangan Sistem Informasi Pariwisata Berbasis Android. Seminar Ilkom Unsri, 170 174.

Bangor, A., Staff, T., Kortum, P., Miller, J., \& Staff, T. (2009). Determining what individual SUS scores mean: adding an adjective rating scale. Journal of Usability Studies, 4(3), 114-123.

Brooke, J. (1996). A “quick and dirty" usability scale. In \& A. L. M. P. W. Jordan, B. Thomas, B. A. Weerdmeester (Ed.), Usability Evaluation in Industry. Taylor \& Francis.

Brooke, J. (2013). SUS-A Retrospective. Journal of Usability Studies, 8(2), 29-40.

Choe, Y., Fesenmaier, D. R., \& Vogt, C. (2017). Information and Communication Technologies in Tourism 2017. Information and Communication Technologies in Tourism 2017. https://doi.org/10.1007/978-3-319-51168-9.

Fernandes, A. P. de C., Santos, D. R., \& Rejowski, M. (2017). Hospitalidade e a Produção Científica em Língua Inglesa sobre Guias de Viagem. Revista Hospitalidade, 14(2), 1-21. https://doi.org/10.21714/2179. 9164.2017v14n2.772.

Fujii, K., Nanba, H., Takezawa, T., \& Ishino, A. (2016). Information and Communication Technologies in Tourism 2016. Information and Communication Technologies in Tourism 2016 https://doi.org/10.1007/978-3-319-28231-2.

Garcia, A. (2013). UX Research | Standardized Usability Questionnaire. Https://Chaione.Com/Blog/Ux-Research-Standardizing-UsabilityQuestionnaires, 1-7. https://chaione.com/blog/category/userresearch/.

Kharis, Santosa, P. I., \& Winarno, W. W. (2019). Evaluasi Usability Pada Sistem Informasi Pasar Kerja Menggunakan System Usablity Scale (SUS). Prosiding Seminar Nasional Sains Dan Teknologi 102019 , 240-245.

Kusuma, W. A., Noviasari, V., \& Marthasari, G. I. (2016). Analisis Usability dalam User Experience pada Sistem KRS Online UMM menggunakan USE Questionnaire. Jurnal Nasional Teknik Elektro Dan Teknologi Informasi (JNTETI), $\quad$ 5(4), 294-301. https://doi.org/10.22146/jnteti.v5i4.277.

Lewis, J. R., \& Sauro, J. (2018). Item Benchmarks for the System Usability Scale. Journal of Usability Studies, 13(3), 158-167.

Mazor-Tregerman, M., Mansfeld, Y., \& Elyada, O. (2017). Travel guidebooks and the construction of tourist identity. Journal of Tourism and Cultural Change, 15(1), 80-98. https://doi.org/10.1080/14766825.2015.1117094.

Mielie, M. (2017). The value of travel guidebooks in the digital age (Vol. 
European Journal of Business and Management Research www.ejbmr.org

20).

http://lup.lub.lu.se/luur/download?func=downloadFile\&recordOId=89 $14895 \&$ fileOId $=8914901$.

Peel, Victoria Margaret and Sorensen, A. (2016). Exploring the Use and Impact of Travel Guidebooks. Channel View Publications.

Pudjoatmodjo, B., \& Wijaya, R. (2016). Tes Kegunaan (Usability Testing) Pada Aplikasi Kepegawaian Dengan Menggunakan System Usability Scale. Seminar Nasional Teknologi Informasi Dan Multimedia 2016, $37-42$.

Ramadhan, D.W., Soedijono, B., Pramono, E. (2019). Pengujian Usability Website Time Excelindo Menggunakan System Usability Scale (SUS) (Studi Kasus: Website Time Excelindo). JIPI (Jurnal Ilmiah Penelitian Dan Pembelajaran Informatika), 4(2), 139-147. https://doi.org/10.29100/jipi.v4i2.977.

Sauro, J. (2018). 5 Ways to Interpret a SUS Score. https://measuringu.com/interpret-sus-score/.

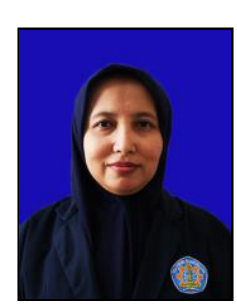

Baroroh Lestari, born in Malang, June 28, 1980 The author is a lecturer at the Department of Business Administration at the State Polytechnic of Malang since 2017 until now. Previously, the author was a lecturer at the University of Lampung, Bandar Lampung (from 2005-2017) and also at Yudharta University, Pasuruan (from 2004-2005). The author's last education is Doctor of Administration Science which was completed in 2011 at Brawijaya University, Malang, East Java, Indonesia. The author actively conducts research and attends seminars, both national and international. In addition, the author is also a reviewer in several journals and seminars. The courses that have been taught include business statistics, business information systems, research methodologies, knowledge management, business information systems and technology, e-business and supply chain management. Currently at the State Polytechnic of Malang the author teaches research methodology courses, introduction to business, supply chain management and financial mathematics.

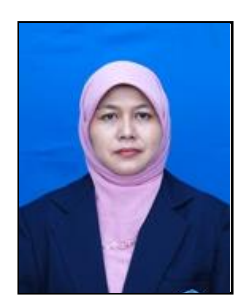

Ita Rifiani Permatasari, was born in Surabaya, November 16, 1961. The author has been a lecturer at the State Polytechnic of Malang since 1990 until now. Completed the Masters program in Management from the Faculty of Economics, Brawijaya University, East Java, Indonesia. The author is active in conducting research and service. In addition, the author is also active in journaling and participating in national and international seminars. The courses taught are currently financial mathematics, statistics, entrepreneurship, business ethics, public relations and banking. Currently, the author also serves as the Head of the D4 Marketing Management Study Program. In addition, the author is also active in the ETU State Polytechnic of Malang.

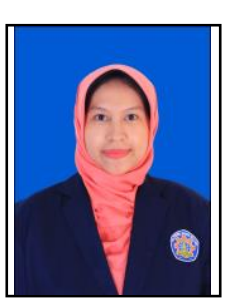

Becik Gati Anjari, was born in Maros, June 12, 1989. Currently a lecturer at the State Polytechnic of Malang. The author completed his undergraduate degree at the Sepuluh Nopember Institute of Technology, Surabaya, East Java, Indonesia and his master's degree was completed at the State University of Malang, Malang East Java, Indonesia. The author is active in conducting research and service. In addition, the author is also active in journaling and participating in national and international seminars. The courses being taught are currently related to computers, IT applications and Multimedia Marketing. 